\title{
A veszélyhelyzeti szabályozás alkotmányos jogfejlődési tapasztalatainak értékelése
}

\author{
DOI 10.17047/Hadtud.2021.31.E.146
}

\begin{abstract}
A természeti katasztrófák, árvizek, járványok, ipari szerencsétlenségek káros következményeinek csökkentéséhez a jogi keretek megteremtésével Alkotmányunk, majd Alaptörvényünk mindig is kiemelt fontossággal foglalkozott. Ezek a jogi keretek, mint különleges jogrend, a szükségállapot és a veszélyhelyzet voltak. A szerzők a rendszerváltástól napjainkig áttekintik a két említett különleges jogrendi elem jelentőségét a katasztrófák elleni védekezés szempontjából, kihirdethetőségük feltételeit, bevezetésük alkotmányos garanciáit, rámutatva a korabeli duplikáció lehetőségére, a veszélyhelyzeti hatalmi centrum, a Kormány intézkedéseinek jelentőségére és a 2023-tól megvalósuló új szabályozás alkotmányos reform jellegére.

KULCSSZAVAK: Alaptörvény kilencedik módosítása, alkotmányos szabályozás, különleges jogrend, szükségállapot, veszélyhelyzet
\end{abstract}

\section{Assessment of the experiencies of constitutional legal development at state of danger's regulation}

In order to reduce the harmful consequences of natural disasters, floods, epidemics and industrial accidents, the Hungarian Constitution and then the Hungarian Basic Law have always been of paramount importance in creating the legal framework. These legal frameworks as a special legal order were state of emergency and state of danger. From the regime change to the present days, the authors review the significance of these two special legal order elements for disaster protection, the conditions of their promulgation, the constitutional guarantees of their introduction, pointing out the possibility of contemporary duplication, the importance of the measures of the center of power in state of danger, the Government and the nature of the constitutional reform of the new regulation from 2023 onwards.

KEYWORDS: Ninth Amendment of the Fundamental Law, constitutional regulation, special legal order, state of emergency, state of danger

\section{Bevezetés}

\footnotetext{
${ }^{1}$ Nemzeti Közszolgálati Egyetem, Rendészettudományi Kar, Katasztrófavédelmi Intézet, Katasztrófavédelmi Müveleti Tanszék tanársegéd - National University of Public Service; e-mail: laszlo.viktoria@uni-nke.hu; https://orcid.org/: 0000-0002-2895-1719.

${ }^{2}$ Nemzeti Közszolgálati Egyetem, Rendészettudományi Kar, Katasztrófavédelmi Intézet, címzetes egyetemi tanár - National University of Public Service; e-mail: muhoray.arpad@uni-nke.hu; https://orcid.org/: 0000-00033832-293x.
} 
A veszélyhelyzetre vonatkozó alkotmányos szintü szabályozás az elmúlt három évtizedben jelentős átalakuláson ment keresztül, és alapvető változás elé néz a közeljövőben is. A szabályrendszer módosításának szükségességét mindig egy-egy, az ország életében bekövetkezett jelentős esemény idézte elő. Ennek megfelelően 1989-től napjainkig alapvetően három nagy korszakra tagolhatjuk a tág értelemben vett katasztrófa típusú válsághelyzetekre vonatkozó alkotmányos rendelkezések rendszerét. A szerzők tágan értelmezik a katasztrófa típusú rendkívüli helyzetek fogalmát, tekintettel arra, hogy a 2023. július 1-jétől hatályba lépő szabályozás „az élet- és vagyonbiztonságot veszélyeztető súlyos esemény” kifejezést használja, mint a veszélyhelyzet kihirdetésére alkalmas rendkívüli helyzetet, amely már túlmutat a természeti és civilizációs katasztrófák körébe sorolható válsághelyzeteken.

A katasztrófavédelmi igazgatás, a védelmi igazgatás és a veszélyhelyzetek összefüggéseit a modern külföldi szakirodalom kevésbé komplexen dolgozza fel, a publikációk inkább a katasztrófavédelmi, megelőzési és mentési szakmai feladatokkal, eljárásrendekkel, szervezeti felépítésekkel, egy-egy jelentősebb természeti vagy civilizációs katasztrófa következményeinek felszámolásával foglalkoznak. A katasztrófavédelmi igazgatás kérdését érintve a veszélyhelyzetet - a szerzőkön kívül - mértékadóan többen vizsgálták disszertációikban, publikációikban, jegyzeteikben, többek között Schweickhardt Gotthilf, Hornyacsek Júlia, Mógor Judit, Endrődi István, Lakatos László, Kádár Pál, Keszely László, Farkas Ádám, Vass Gyula, Bognár Balázs, Kátai-Urbán Lajos és Bárdos Zoltán. Azonban e szerzők munkássága nem terjedt ki részletesen a veszélyhelyzetek kihirdetése esetén a védelmi igazgatás konkrét közigazgatási feladataira, és nem terjedt ki a veszélyhelyzet jogi szabályozásának, fejlődésének történeti áttekintésére.

Szükséges egy újfajta megközelítés a veszélyhelyzetek kihirdetését igénylő természeti és civilizációs katasztrófák elleni védekezés során a jogalkotási fejlődés igazolása és a további módosítási javaslatok megfogalmazása céljából. A tudományos probléma abban is megfogalmazható, hogy a közigazgatás és a szakma képviselői sem érzékelik mindenkor, hogy a katasztrófák következményei káros hatásának csökkentése hatékonyan csak a katasztrófavédelmi és a védelmi igazgatás szereplöinek szoros együttmüködésében valósitható meg, amelynek meghatározó fázisa a rendkívüli jogrend, a veszélyhelyzet kihirdetésének idöszaka. ${ }^{3}$

A veszélyhelyzetre vonatkozó alkotmányos szintü szabályozás történetében az első időszak a rendszerváltozás, amelyet követően a demokratikus átmenet indokolttá tette, hogy a Magyar Köztársaság Alkotmánya a jogállamiság keretei között újra szabályozza a katasztrófa típusú rendkívüli helyzetekkel szembeni fellépést, két minősített időszak bevezetésének lehetővé tételével.

A második jelentős mérföldkő az Alaptörvény 2012. január 1-jén történt hatályba lépése. Az ezredforduló után a Magyarországon pusztító árvizek és az ajkai vörösiszap-katasztrófa teremtettek hazánk életében olyan rendkívüli helyzeteket, amelyek kezelése során a szabályrendszer alkalmazhatóságával kapcsolatosan tapasztalt ellentmondások és nehézségek megkövetelték a vonatkozó rendelkezések alkotmányos szintü módosításának szükségességét.

\footnotetext{
${ }^{3}$ Muhoray 2019, 61.
} 
Ezt követően a szabályozás legnagyobb erőpróbáját a hazánkban tavaly tavasszal megjelent koronavírus-járvánnyal és szerteágazó következményeivel szembeni hatékony fellépés jelentette. A járvány kezelése során számos szabályozási ellentmondás került a felszínre, melyet az alkotmányozó az Alaptörvény 2023. július 1-jén hatályba lépő kilencedik módosításának keretei között orvosolt. Ez utóbbit tekinthetjük a szabályrendszer harmadik jelentős változásának.

A katasztrófa típusú rendkívüli helyzetekkel szembeni hatékony fellépés során meghatározó fázis a rendkívüli jogrend, melyek közül az eddigi alkotmányszintü szabályozásnak megfelelően a veszélyhelyzet, illetve egy időben a szükségállapot is kihirdethető volt.

Lényeges annak tisztázása, hogy a katasztrófák miatti lehetséges különleges jogrend esetén mely példák alkalmazhatók napjainkban is a katasztrófák hatékony kezeléséhez a katasztrófavédelmi és védelmi igazgatási feladatrendszerben. ${ }^{4}$

\section{Az Alkotmány veszélyhelyzetre vonatkozó rendelkezései az Alaptörvény hatályba lépéséig}

A Magyar Népköztársaság Alkotmányát ${ }^{5}$ az 1989. október 23-án kihirdetett ún. alkotmányozó törvény ${ }^{6}$ módosította, melynek következtében az Alkotmány három különleges jogrendi időszakot rögzített: a rendkívüli állapotot, a szükségállapotot és a veszélyhelyzetet. A szabályrendszer a katasztrófa típusú rendkívüli helyzeteket, mint az adott különleges jogrendi esetkör kihirdetésére okot adó eseményeket egyrészt a szükségállapot, másrészt a veszélyhelyzet tényállásaiban rögzítette, ezzel némiképp összemosva a két esetkör alkalmazhatóságát.

Az Országgyülés jogosult volt szükséghelyzet esetén, azaz az alkotmányos rend megdöntésére vagy a hatalom kizárólagos megszerzésére irányuló fegyveres cselekmények, továbbá az állampolgárok élet- és vagyonbiztonságát tömeges méretekben veszélyeztető, fegyveresen vagy felfegyverkezve elkövetett súlyos eröszakos cselekmények, elemi csapás vagy ipari szerencsétlenség esetén szükségállapotot kihirdetni. Az Országgyülés ezen döntéséhez az országgyülési képviselők kétharmadának szavazata volt szükséges. ${ }^{7}$ Emellett a Kormány kötelezettsége volt veszélyhelyzet esetén, az állampolgárok élet- és vagyonbiztonságát veszélyeztető elemi csapás, illetőleg következményeinek az elhárítása, valamint a közrend és a közbiztonság védelme érdekében megtenni a szükséges intézkedéseket. $^{8}$

Szükségállapot idején a kivételes hatalom gyakorlására a köztársasági elnök volt jogosult, aki rendeleti úton rendkívüli intézkedéseket vezethetett be, amelyek harminc napig maradtak hatályban. A köztársasági elnök köteles volt intézkedéseiröl haladéktalanul tájékoztatni az Országgyülés elnökét. Az Országgyülés - akadályoztatása esetén az Országgyülés Honvédelmi Bizottsága - a köztársasági elnök által bevezetett rendkívüli

\footnotetext{
${ }^{4}$ Muhoray 2019, 61-62.

5 1949. évi XX. törvény a Magyar Népköztársaság Alkotmánya.

${ }^{6}$ 1989. évi XXXI. törvény az Alkotmány módosításáról.

${ }^{7}$ Magyar Köztársaság Alkotmánya (Alkotmány) 19. § (3) bekezdés i) pont, (4) bekezdés.

${ }^{8}$ Alkotmány 35. $§(1)$ bekezdés i) pont.
} 
intézkedések hatályát meghosszabbíthatta, továbbá az intézkedések alkalmazását felfüggeszthette. ${ }^{9}$

Az Alkotmány rögzítette, hogy az Országgyülés akadályoztatása esetén a köztársasági elnök jogosult a szükségállapot kihirdetésére. ${ }^{10}$ Meghatározta, hogy az Országgyülés mely esetekben van akadályoztatva e döntés meghozatalában - ha nem ülésezik, és összehívása az idő rövidsége, továbbá a szükségállapotot kiváltó események miatt elháríthatatlan akadályba ütközik -, valamint azt is, hogy az akadályoztatás tényét, továbbá a szükségállapot kihirdetésének indokoltságát az Országgyülés elnökének, az Alkotmánybíróság elnökének és a Minisztertanács elnökének együttesen kell megállapítania. ${ }^{11}$

Az Országgyülésnek joga volt az akadályoztatásának megszünése utáni első ülésén a szükségállapot kihirdetésének indokoltságát felülvizsgálni, és az országgyülési képviselők kétharmadának a szavazatával dönteni az alkalmazott intézkedések jogszerüségéről.

Szükségállapot idején az alkotmányos rendelkezések értelmében az Alkotmánybíróság müködése nem volt korlátozható, és az Országgyülés - akadályoztatása esetén az Országgyülés Honvédelmi Bizottsága - folyamatosan ülésezett. Az Országgyülés nem mondhatta ki a feloszlását és nem volt feloszlatható. Ha az Országgyülés megbízatása szükségállapot idején járt le, a megbízatás a szükségállapot megszünéséig meghosszabbodott. A köztársasági elnöknek jogában állt a feloszlott vagy feloszlatott Országgyülést szükséghelyzet esetén ismét összehívni. ${ }^{12}$ Az Alkotmányban tételesen meghatározott abszolút jogok - az Alkotmány 54-56. §-ban, az 57. § (2)-(4) bekezdésében, a 60. §-ban, a 66-69. §ban és a 70/E. §-ban megállapított alapvető jogok - a minősített időszakokban sem voltak korlátozhatók és felfüggeszthetők. ${ }^{13}$

Veszélyhelyzetben a kivételes hatalmi centrum a Kormány volt, amely az Országgyülés felhatalmazása alapján egyes törvények rendelkezéseitől eltérő rendeleteket és intézkedéseket hozhatott. ${ }^{14}$

A fenti szabályozás alapján megállapítható, hogy az állampolgárok élet-és vagyonbiztonságát veszélyeztető elemi csapás, azaz természeti katasztrófa bekövetkezése esetén az alkotmányozó két különböző jogrendi időszak megvalósulását tette lehetővé, azok elkülönítését csupán a „tömeges méretü” veszélyeztetés kitételhez kötötte. Ezek a rendelkezések lehetőséget teremtettek a duplikációra, hiszen az egyértelmü elhatárolást biztosító súlyosság, gyakoriság vagy területi egység küszöbértéke nem volt rögzítve a szabályrendszerben.

Indokolt lett volna egy súlyossági küszöb meghúzása, melynek segítségével egy szakmaikormányzati értékelés során eldönthető lett volna, hogy mi minősül az élet- és vagyonbiztonságot tömeges méretekben veszélyeztető elemi csapásnak vagy ipari szerencsétlenségnek, melyek azok a helyzetek, ahol már nem elegendőek a kormányzati intézkedések, hanem szükséges a szükségállapot kihirdetése a katasztrófa kezelése

\footnotetext{
${ }^{9}$ Alkotmány 19/C. $\S$.

${ }^{10}$ Alkotmány 19/A. $§(1)$ bekezdés.

${ }^{11}$ Alkotmány 19/A. § (2)-(3) bekezdés.

${ }^{12}$ Alkotmány 19/B.§ (6) bekezdés, 19/C. $\S(5)$ bekezdés, 28/A. §.

${ }^{13}$ Alkotmány 8 . § (4) bekezdés.

${ }^{14}$ Alkotmány 35. § (3) bekezdés.
} 
érdekében. ${ }^{15}$

Az alkotmányos rendelkezések között kizárólag a szükséghelyzet meghatározásánál szerepelt az elemi csapás mellett az ipari szerencsétlenség, mint a szükségállapot kihirdetésére okot adó esemény, a veszélyhelyzet definíciója mindössze az elemi csapás illetőleg következményeinek az elhárítását tartalmazta.

A polgári védelmi törvény azonban a veszélyhelyzetet már a szükséghelyzetet el nem érő mértékü, az állampolgárok élet- és vagyonbiztonságát vagy a környezetet veszélyeztető természeti csapás, illetőleg ipari baleset okozta állapotként definiálja, és a „különösen” szófordulattal példálózó felsorolást ad, hogy mely események válthatják ki a veszélyhelyzetet. Ezek a következők:

a) súlyos, több embernél halálos lefolyású tömeges megbetegedést előidéző kórokozó megjelenése, amely kórokozót ürítő embertől, kórokozót tartalmazó holttesttől, kórokozóval szennyezett élelmiszerből, vízből, talajból, tárgyról, anyagról, levegőből, állatból vagy állati tetemből származik;

b) ivóvíz célú vízkivétellel érintett felszíni vizek haváriaszerü szennyezése;

c) kedvezőtlen meteorológiai viszonyok következtében fellépő légszennyezettségi állapot, amelynek során bármely légszennyező anyag koncentrációja a 30 perces levegőminőségi határértéket a megengedett esetszámon felül meghaladja;

d) a környezet veszélyes hulladékkal való közvetlen és súlyos szennyezése;

e) az atomenergia alkalmazását szolgáló létesítményben, berendezésben radioaktív anyaggal végzett tevékenység során vagy nukleáris ürobjektum becsapódását követően a biztonságot kedvezőtlenül befolyásoló és a lakosság nem tervezett sugárterhelését előidéző esemény;

f) ipari létesítményben, továbbá szénhidrogén-kitermelés során vagy veszélyes anyag tárolása és szállítása közben bekövetkező baleset, amikor a szabadba kerülő mérgező anyag az emberi életet vagy egészséget, továbbá a környezetet tömeges méretekben és súlyosan veszélyezteti; $g$ ) árvízvédekezés során, ha az előrejelzések szerint az áradó víz az addig észlelt legmagasabb vízállást megközelíti és további jelentős áradás várható, vagy elháríthatatlan jégtorlasz keletkezett, illetőleg, ha töltésszakadás veszélye fenyeget;

h) háromnál több napon keresztül tartó folyamatos, intenzív hóesés;

i) régión belül egyidejüleg járhatatlan vasútvonal, föút, valamint legalább öt mellékút;

j) belvízvédekezés során, ha a belvíz lakott területeket, ipartelepeket, fő közlekedési utakat, vasutakat veszélyeztet és további elöntések várhatók. ${ }^{16}$

A fenti meghatározásból kitűnik, hogy a polgári védelemi törvény az Alkotmánnyal ellentétben - a szükséghelyzetet el nem érő mértékű - ipari balesetet is rögzítette a kiváltó okok között.

A 2000-es években számos súlyos természeti katasztrófa következett be Magyarországon, azonban a következmények elhárítása, felszámolása a veszélyhelyzet keretei között történt, nem került sor szükségállapot kihirdetésére. ${ }^{17}$

A polgári védelmi törvény a különleges jogrendben alkalmazható szabályrendszeren

\footnotetext{
${ }^{15}$ Muhoray 2019, 62-63.

${ }^{16}$ A polgári védelemről szóló 1996. évi XXXVII. törvény 2. § (2) bekezdés.

${ }^{17}$ Muhoray 2019, 62.
} 
belül rögzítette azokat az intézkedéseket, amelyeket szükségállapot idején a köztársasági elnök, valamint amelyeket a Kormány veszélyhelyzetben a veszélyhelyzet elhárításhoz szükséges mértékben bevezethetett. A Kormány a honvédelmi törvény 202-204; 206-208; 213-218; 220-221; 234; 243; 245-247. §-aiban meghatározott intézkedéseket, ${ }^{18}$ míg a köztársasági elnök a honvédelmi törvény 202-207; 210-234; 239-243; 245-248. §-aiban, valamint más törvényekben meghatározott rendkívüli intézkedéseket vezethetett be. ${ }^{19}$

Mindezek alapján megállapítható, hogy a rendszerváltozást követően, az Alaptörvény 2012. január 1-jén történt hatályba lépéséig a katasztrófa típusú rendkívüli helyzetek kezelése az alkotmányos szabályrendszer alapján két különleges jogrendi esetkörben - minösített időszakban - valósulhatott meg: szükségállapot kihirdetését követően a köztársasági elnök rendkívüli intézkedéseivel, valamint veszélyhelyzetben a Kormány által foganatosított intézkedésekkel.

A vonatkozó rendelkezések a szükségállapotra vonatkozóan részletesebb szabályozást biztosítottak, a kivételes hatalom gyakorlását ellensúlyozó garanciáknak a szabályrendszerbe történt beemelésével. A veszélyhelyzet vonatkozásában az alkotmányozó csupán a Kormány intézkedési kötelezettségét rögzítette, részletszabályokat - a veszélyhelyzet kihirdetésének jogosultját, a kihirdetéshez szükséges országgyülési képviselői szavazatarányt, a veszélyhelyzetre vagy az akkor megalkotott rendeletek hatályára vonatkozó időbeli korlátot, illetve egyéb alkotmányos biztosítékot - nem tartalmazott.

A szükségállapotra és a veszélyhelyzetre vonatkozó eltérő mértékü szabályozottság mellett fontos kiemelni, hogy az Alkotmány nem biztosított egyértelmü elhatárolást arra vonatkozóan, hogy az élet- és vagyonbiztonságot veszélyeztető elemi csapás vagy ipari szerencsétlenség mikor tekinthető tömeges méretünek - mikor indokolt szükségállapotot kihirdetnie az Országgyülésnek és mely esetekben minősíthető a konkrét helyzet veszélyhelyzetnek, amikor a Kormányt terheli intézkedési kötelezettség -, amely a konkrét rendkívüli helyzetek bekövetkezése során megnehezítette a jogértelmezést.

A katasztrófák szükséghelyzetté, vagy veszélyhelyzetté nyilvánítása függött volna a kialakult helyzet súlyosságától, valamint attól, hogy a katasztrófa következményeinek felszámolása az államigazgatás melyik szintjének, mint hatalmi központnak, a Kormánynak, az Országgyülésnek, ez utóbbi akadályoztatása esetén a köztársasági elnöknek az irányításával lett volna a legeredményesebb, leghatékonyabb. Valójában mindkét rendkívüli jogrend szükségességének elfogadása egy kormányzati szakmai értékelést követő politikai döntést igényelt volna. Azaz a Kormány vagy döntött és kihirdette a veszélyhelyzetet, vagy mérlegelése alapján intézkedési kompetenciáját meghaladónak minősíthette volna a súlyos helyzetet, és az Országgyülésnél kezdeményezte volna törvény alkotását, vagy országgyülési határozat meghozatalát a szükséghelyzet kihirdetésére.

A súlyosság mellett a katasztrófák következményeinek felszámolásában a veszteségek csökkentésének sikeressége nagymértékben függ az időtényezőtől. A gyors, határozott intézkedések megtétele érdekében veszélyhelyzeti rendeletalkotásra össze kell ülnie a Kormánynak, míg szükséghelyzetet elrendelő törvény vagy országgyülési határozat

\footnotetext{
${ }^{18}$ A honvédelemröl szóló 1993. évi CX. törvény 199. § (3) bekezdés.

${ }^{19}$ A honvédelemröl szóló 1993. évi CX. törvény 199. § (2) bekezdés.
} 
elfogadására a Parlamentnek is, majd ez utóbbiak valamelyikének elfogadása után az élet- és vagyonbiztonságot tömeges méretekben veszélyeztető elemi csapás vagy ipari szerencsétlenség leküzdésére a köztársasági elnök döntött volna a Hvt. rendkívüli intézkedések fejezetében meghatározott intézkedések bevezetéséről.

Látható, hogy egy megfelelö jogosítványokkal felruházott Kormány jóval hamarabb tudott határozott veszélyhelyzeti intézkedéseket hozni a katasztrófák felszámolására, mint a Kormány, az Országgyülés és a köztársasági elnök jogilag és idöben egymásra épülö munkájával tudtak volna alkotni szükséghelyzet bevezetésekor.

Talán ez az időtényező szempont is alátámasztotta, hogy a 2001-es tiszai, a 2002-es dunai, a 2006-os egyidejü dunai és tiszai, 2010-es borsod-abaúj-zempléni árvizeknél és a 2010 évi vörösiszap katasztrófánál is a veszélyhelyzet és nem a szükséghelyzet lett kihirdetve.

Valamennyi említett jelentősebb veszélyhelyzet után a tapasztalatok megvonása között mindig megjelentek az olyan jogalkotói igények, melyek a jobb, hatékonyabb védekezés megvalósíthatóságát célozták. Közülük is kiemelkedik a 2001-es tiszai és a 2002-es dunai árvizek után létrehozott Katasztrófavédelmi Jogszabályokat Vizsgáló Tárcaközi Bizottság (KJTB) által megfogalmazott feladatcsomag, amely a közigazgatás és a védelmi igazgatás reformjából adódó feladatokra irányult. Nem kevésbé voltak fontosak a 2010-es árvizek és a vörösiszap katasztrófa következményeinek felszámolási tapasztalatai, amelyek magának a védelmi igazgatásnak, az egész magyar katasztrófavédelemnek a megújítását alapozták meg az új Kat. elfogadása által a tűzoltóság államosításával, az önálló iparbiztonsági ágazat létrehozásával, a polgári védelem megújításával és a veszélyhelyzet, mint katasztrófavédelmi különleges jogrendi elem egyedülikénti megerősítésével egyetemben.

\section{A veszélyhelyzet alkotmányos szintü szabályozása 2012. január 1-jétöl}

A közigazgatás megreformálása, a katasztrófavédelmi rendszer korszerüsítése érdekében számos alapvető jogszabályváltozásra került sor a 2010-es évek elején. Ezek között kiemelt helyet töltött be az Alaptörvény hatályba lépése 2012. január 1-jén. Az alkotmányos szintü szabályozás öt, majd 2016-tól hat különleges jogrendi időszakot különböztetett meg, melyek egyike a katasztrófa típusú rendkívüli helyzetek kezelését szolgáló veszélyhelyzet.

Az Alaptörvény a veszélyhelyzetre vonatkozó szabályozást az 53. cikkben - egy helyen rögzíti. A veszélyhelyzet kihirdetésére a Kormány jogosult az élet- és vagyonbiztonságot veszélyeztető elemi csapás vagy ipari szerencsétlenség esetén, valamint ezek következményeinek az elhárítása érdekében. E különleges jogrendi esetkör kihirdetését követően a kivételes hatalmi centrum a Kormány, amely rendeleti úton sarkalatos törvényben meghatározott rendkívüli intézkedéseket vezethet be. Rendeleteivel - sarkalatos törvényben meghatározottak szerint - egyes törvények alkalmazását felfüggesztheti, törvényi rendelkezésektől eltérhet, valamint egyéb rendkívüli intézkedéseket hozhat.

A Kormány kivételes hatalmának ellensúlyozása érdekében az alkotmányozó több biztosítékot is beemelt a szabályozásba. Egyrészt rendeletei hatályát kettős időkorláthoz köti, amikor rögzíti, hogy a veszélyhelyzetben megalkotott rendeletek tizenöt napig maradnak hatályban, valamint ezeknek a rendeleteknek a hatálya a veszélyhelyzet megszünésével 
hatályát veszti. Másrészt az Országgyülés kontrollszerepének megvalósítását szolgálja az a garanciális szabály, amely kimondja, hogy a Kormány rendeleteinek - 15 napos - hatályát a parlament felhatalmazása alapján hosszabbíthatja meg. ${ }^{20}$

Az Alaptörvény a különleges jogrend valamennyi esetkörére - így a veszélyhelyzetre is meghatároz közös garanciális szabályokat, amelyek értelmében az Alaptörvény alkalmazása nem függeszthető fel, az Alkotmánybíróság müködése nem korlátozható. Az általános szabályok között szerepel továbbá, hogy különleges jogrend idején az alapvető jogok gyakorlása - az abszolút jogok kivételével - felfüggeszthető vagy az Alaptörvényben meghatározott mértéken túl korlátozható. ${ }^{21}$ A korlátozhatatlan, abszolút jogok a következők:

-az élethez és az emberi méltósághoz való jog;

-a kínzás, embertelen, megalázó bánásmód vagy büntetés tilalma;

-a szolgaság, emberkereskedelem tilalma;

-az önkéntes hozzájárulás nélküli orvosi vagy tudományos kísérlet tilalma;

-az emberi fajnemesítés, az emberi test és testrészek haszonszerzési célú felhasználása, valamint az emberi egyedmásolás tilalma;

-az ártatlanság vélelme;

-a védelemhez való jog;

- a nullum crimen sine lege;

- a többszöri elítélés tilalma. ${ }^{22}$

Az általános biztosítékok közé sorolható, hogy a különleges jogrendet a különleges jogrend bevezetésére jogosult szerv megszünteti, ha kihirdetésének feltételei már nem állnak fenn, valamint az is, hogy a különleges jogrendben alkalmazandó részletes szabályokat sarkalatos törvény határozza meg. ${ }^{23}$

A veszélyhelyzet vonatkozásában a részletszabályozást a katasztrófavédelmi törvény rögzíti. A jogszabály meghatározza a veszélyhelyzet fogalmát, amely szerint az Alaptörvény 53. cikkében meghatározott olyan helyzet, amelyet elemi csapások, természeti eredetü veszélyek, ipari szerencsétlenség, civilizációs eredetű veszélyek és egyéb eredetü veszélyek válthatnak ki. A jogalkotó a „különös” szófordulattal élve példálózó jelleggel három fö csoportba sorolja a kiváltó eseményeket. A három kategórián belül szintén példálózó jelleggel alcsoportokba rendezve további kiváltó eseményeket határoz meg, mint például: több napon keresztül tartó kiterjedő, folyamatos, intenzív, megmaradó hóesés vagy hófúvás; a veszélyes anyagokkal és hulladékokkal történő tevékenység során a szabadba kerülő anyag az emberi életet, egészséget, továbbá a környezetet tömeges méretekben és súlyosan veszélyezteti; tömeges megbetegedést okozó humánjárvány vagy járványveszély, valamint állatjárvány stb. ${ }^{24}$

A rendszerváltozást követően a minősített időszakok/különleges jogrendi esetkörök száma háromról négyre, majd ötre bővült az Alkotmányban: 1994-ben a váratlan fegyveres

\footnotetext{
${ }^{20}$ Magyarország Alaptörvénye (Alaptörvény) 53. cikk.

${ }^{21}$ Alaptörvény 54. cikk (1)-(2) bekezdés.

${ }^{22}$ Alaptörvény II., III. cikke, XXVIII. cikk (2)-(6) bekezdés.

23 Alaptörvény 54. cikk.

${ }^{24}$ A katasztrófavédelemről és a hozzá kapcsolódó egyes törvények módosításáról szóló 2011. évi CXXVIII. törvény 44. .
} 
támadás, majd 2004-ben a megelőző védelmi helyzet esetkörével, melyek esetében az alapvető jogok gyakorlásának korlátozását vagy felfüggesztését nem tette lehetővé a szabályozás. A korábbi alkotmányos szabályanyag a fenti általános biztosítékok közül három minősített időszak - a rendkívüli állapot, a szükségállapot és a veszélyhelyzet vonatkozásában tette lehetővé az alapvető jogok gyakorlásának korlátozását vagy felfüggesztését az abszolút jogok kivételével, valamint az Alaptörvényhez hasonló módon azt rögzítette, hogy a részletszabályokat magas szintü jogszabálynak, alkotmányerejü törvénynek kell megállapítania, de ezt az előírást is csak a rendkívüli állapot és a szükségállapot vonatkozásában tartalmazta. ${ }^{25}$

A többi alkotmányos biztosítékot - az Alkotmánybíróság müködésének korlátozhatatlansága, az Alkotmány alkalmazásának felfüggeszthetetlensége, a minősített időszakban megalkotott rendeletek a minősített időszak megszünésével hatályukat vesztik csupán a rendkívüli állapotra és a szükségállapotra vonatkozóan tartalmazta a szabályozás, a veszélyhelyzet vonatkozásában nem.

Az Alaptörvény rögzíti azt is, hogy a veszélyhelyzet kihirdetésére a Kormány jogosult. Az Alkotmány vonatkozó rendelkezései szerint veszélyhelyzetben a Kormánynak meg kellett tennie a szükséges intézkedéseket, azonban a veszélyhelyzet Kormány általi kihirdetésének rögzítése hiányzott a szabályrendszerből, mint ahogy a rendeletei hatályára vonatkozó időbeli korlátok meghatározása is. Az Alaptörvény viszont rögzíti, hogy a Kormány rendeletei tizenöt napig maradnak hatályban - kivéve, ha a Kormány az Országgyülés felhatalmazása alapján a rendelet hatályát meghosszabbítja -, továbbá a veszélyhelyzet megszűnésével hatályukat vesztik. $^{26}$

Az Alaptörvény újításai között fontos még kiemelni, hogy a szükségállapot kihirdetésére okot adó események közül az alkotmányozó kivette az állampolgárok élet- és vagyonbiztonságát tömeges méretekben veszélyeztető elemi csapás vagy ipari szerencsétlenség esetét, ezáltal a szükségállapot tisztán rendészeti típusú különleges jogrendi esetkörré vált.

A veszélyhelyzet tényállásának meghatározásából kiemelte a közrend és a közbiztonság védelme érdekében történő kihirdethetőséget, továbbá az állampolgárok élet- és vagyonbiztonságát veszélyeztető elemi csapás mellé beemelte az ipari szerencsétlenség esetét, mint a veszélyhelyzet kihirdetésére okot adó eseményt. Ezáltal a veszélyhelyzet kizárólag a katasztrófák kezelésére szolgáló időszakká alakult. A profiltisztítás folytán a szükségállapot a polgárháborús eseményekre és a lázadás eseteire, míg az ipari szerencsétlenségnek a veszélyhelyzetbe történő beemelésével és a „közrend és közbiztonság” kitétel elhagyásával a veszélyhelyzet esetköre a katasztrófa típusú helyzetekre korlátozódik. A szabályozás ennek folytán logikusabbá vált. ${ }^{27}$

\section{A 2023. július 1-jétől hatályba lépö szabályozás}

\footnotetext{
${ }^{25}$ Alkotmány 8 . $\S(4)$ bekezdés, 19/D. $\S, 35$. $§(3)$ bekezdés,

${ }^{26}$ Alaptörvény 53. cikk (3)-(4) bekezdés.

${ }^{27}$ Jakab, Till 2016, 509.
} 
A veszélyhelyzetre vonatkozó alkotmányos szabályozást, annak megújítását napjainkban több tényező is indokolja, alátámasztja. Így ezek sorában figyelmet érdemel, hogy Magyarország Nemzeti Biztonsági Stratégiája úgy rendelkezik, hogy „Különös figyelmet kell fordítani a katasztrófakockázat átfogó csökkentésére. Magyarországnak rendelkeznie kell olyan képességekkel, amelyek komplex megelözési és katasztrófakockázat-csökkentési rendszert alkotnak, és természeti vagy ipari katasztrófák, valamint egészségügyi válsághelyzetek és tömeges sérülésekkel és rombolással járó támadás esetén hatékonyan reagálnak a lakosság életének, egészségének, anyagi javainak védelme és a károk minimalizálása érdekében". ${ }^{28}$

A másik döntő tényező, mely tapasztalataira figyelemmel kell lenni, hogy a koronavírusjárvány 2020. márciusában Magyarországon is megjelent. Ismeretlen, eddig nem létező rendkívüli helyzettel szemben kellett a Kormánynak fellépnie. A járvány negatív következményeinek - amelyek az élet minden területén megjelentek összetett, elöre nem látható, egymással kölcsönhatásban álló folyamatokat indítva el - kezelése érdekében a Kormány 2020. március 11-én az ország egész területére kiterjedő hatállyal kihirdette a veszélyhelyzet, ${ }^{29}$ ezáltal a rendszerváltozást követően először Magyarország teljes területén különleges jogrend valósult meg.

A járvány magyarországi megjelenése idején a veszélyhelyzetre vonatkozó alapvető rendelkezéseket az Alaptörvény, a részletes szabályanyagot a katasztrófavédelmi törvény tartalmazta. A rendkívüli helyzet során fókuszba kerültek a különleges jogrendre és azon belül a veszélyhelyzetre vonatkozó szabályrendszer fellelhető ellentmondásai. Ezek közül kiemelendő a veszélyhelyzet kihirdethetőségének kérdése, a Kormány által alkotott rendeletek időbeli hatálya és országgyülési felhatalmazás alapján történő meghosszabbítási lehetősége, a hatékony fellépéshez elengedhetetlenül szükséges kormányzati koordináció kérdése. Fontos még megemlíteni a - katasztrófavédelmi törvényben rögzített - bevezethető rendkívüli intézkedések körét, a törvény alapvetően ágazati szellemiségét és - az Alaptörvénnyel nem teljesen összhangban álló - fogalomrendszerét, az Országgyülés akadályoztatásának esetére vonatkozó alkotmányos szintű szabályozás és egyéb speciális garanciák hiányát és általánosságban a szabályanyag statikus, kazuisztikus jellegét. ${ }^{30}$

A harmadik fontos tényező, hogy a 21. századi hatékony válságkezelést nehezítő ellentmondásoknak, hiányosságoknak a kiküszöbölése érdekében 2020. december 22-én sor került az Alaptörvény kilencedik módosításának kihirdetésére. ${ }^{31}$ A módosítás különleges jogrendre vonatkozó szabályrendszere 2023. július 1-jén lép hatályba. Az új szabályozás alkotmányos reformként értelmezhető, a jogalkotói igényt kumulálva a rendszerszintü megújítás a „... korszerübb, a változó biztonsági környezethez jobban alkalmazkodó és az elmúlt évek válságkezeléseinek tapasztalataira építö, hatékony rendszer jövőbeni kialakitását szolgálja". ${ }^{32}$

A módosítás valamennyi különleges jogrendi esetkörre - a tágan értelmezhető katonai típusú hadiállapotra, a rendészeti típusú szükségállapotra és a katasztrófa típusú

\footnotetext{
${ }^{28}$ 1163/2020. (IV. 21.) Korm. határozat Magyarország Nemzeti Biztonsági Stratégiájáról. 174.

${ }^{29}$ 40/2020. (III. 11.) Korm. rendelet veszélyhelyzet kihirdetéséröl.

${ }^{30}$ László 2021, 43-76.

${ }^{31}$ Magyarország Alaptörvényének kilencedik módosítása. 11. cikk. Magyar Közlöny 2020/285. 10128-10131.

${ }^{32}$ Az Alaptörvényhez és annak módosításaihoz tartozó indokolások. Indokolások Tára 2020/161. 1894.
} 
veszélyhelyzetre - közös szabályokat állapít meg. Mindhárom különleges jogrendi időszakban a kivételes hatalom jogosultja a Kormány, valamint továbbra is rendeleti kormányzás valósul meg. ${ }^{33}$

A hatályos Alaptörvényben rögzített általános alkotmányos garanciák átvétele mellett a tervezett reform új biztosítékokat is beépít a szabályozásba, ezzel viszonyleg erős, egységes kontrollrendszert alkotva. Az általános garanciális szabályok a következők. ${ }^{34}$

-Az Alaptörvény alkalmazása nem függeszthető fel.

-Az alapvető jogok gyakorlása - az abszolút jogok kivételével - felfüggeszthető vagy az Alaptörvényben meghatározott mértéken túl korlátozható.

-Az Alkotmánybíróság müködése nem korlátozható.

-A különleges jogrendet a különleges jogrend kihirdetésére jogosult szerv megszünteti, ha kihirdetésének feltételei már nem állnak fenn.

-A különleges jogrendben alkalmazandó részletes szabályokat sarkalatos törvény határozza meg.

-A különleges jogrend idején alkotott rendelet a különleges jogrend megszünésekor hatályát veszti.

Az új biztosítékok között szerepel, hogy a Kormányt a különleges jogrend idején alkotott rendeleteire vonatkozó folyamatos tájékoztatási kötelezettség terheli a köztársasági elnök, az Országgyülés elnöke, valamint az Országgyülés tárgykör szerint feladat- és hatáskörrel rendelkező állandó bizottsága irányába. Ezen túl az Országgyülés a Kormány rendeleteit jogosult hatályon kívül helyezni. A hatályon kívül helyezett rendeletet - egy kivétellel - a Kormány azonos tartalommal nem alkothatja meg újra. ${ }^{35}$

Mindezek a garanciák a Kormány kivételes hatalomkoncentrációjának ellensúlyozása érdekében a köztársasági elnök és az Országgyülés Kormány felett gyakorolt kontrollszerepét erősítik, ellentétben a hatályos rendelkezésekkel, amelyek szerint veszélyhelyzetben a Kormány megnövekedett hatalmának ellentételezésére kizárólag egy eszköz szolgál: a Kormány az általa alkotott rendeletek hatályát az Országgyülés felhatalmazása alapján hosszabbíthatja meg. Új garanciális szabály, hogy a Kormány különleges jogrend idején köteles minden olyan intézkedést megtenni, amely az Alkotmánybíróság és az Országgyülés folyamatos müködését szavatolja. ${ }^{36}$

A 2023-ban hatályba lépő rendelkezések az Országgyülés akadályoztatása esetén fennálló köztársasági elnöki helyettesítési jogkört - az Országgyülés akadályoztatása esetén a köztársasági elnök lesz jogosult a hadiállapot kihirdetésére, a szükségállapot kihirdetésére és meghosszabbítására, valamint arra, hogy felhatalmazza a Kormányt a veszélyhelyzet meghosszabbítására $-{ }^{37}$ némi eltéréssel, a köztársasági elnök szerepének erősítésével kiterjesztik a veszélyhelyzet időszakára is, ezáltal a legfontosabb döntések meghozatala valamennyi különleges jogrendi esetkör esetén biztosítottá válik.

\footnotetext{
${ }^{33}$ Magyar Közlöny 2020/285. 10130.

${ }^{34}$ Alaptörvény 54. cikk, 49. cikk (5) bekezdés, 50. cikk (6) bekezdés, 53. cikk (4) bekezdés.

${ }^{35}$ Magyar Közlöny 2020/285. 10130.

${ }^{36}$ Magyar Közlöny 2020/285. 10130.

${ }^{37}$ Magyar Közlöny 2020/285. 10130.
} 
A vonatkozó szabályozás alapján a veszélyhelyzetet továbbra is a Kormány jogosult kihirdetni. Egy teljesen új szabályozási megoldással, a szükségállapot vonatkozásában alkalmazott módszerrel azonosan, az időbeli korlátot az alkotmányozó már nem a Kormány által megalkotott rendeletek hatályához köti - a Kormány rendelete tizenöt napig marad hatályban,$-{ }^{38}$ hanem a különleges jogrendi időszak tartamához: a veszélyhelyzet 30 napra hirdethető ki. ${ }^{39}$ A reform a hatályos rendelkezésekkel egyezően biztosítja a veszélyhelyzet parlamenti felhatalmazás alapján történő meghosszabbításának lehetőségét, de az Alaptörvényben foglaltakhoz képest részletesebb szabályozással. A tervezett 51. cikk (4) bekezdése ugyanis meghatározza, hogy a felhatalmazásról az Országgyülés a jelen lévő országgyülési képviselők kétharmadának szavazatával dönt. ${ }^{40}$ Célszerü lett volna ezen túl - a szükségállapotra vonatkozó rendelkezésekkel azonos módon - a meghosszabbítás időtartamának meghatározása is az egyértelmü és teljeskörü szabályozás megteremtése érdekében.

Fontos változás a hatályos Alaptörvényben foglaltakhoz képest a veszélyhelyzet kihirdetését megalapozó események körének módosítása. A veszélyhelyzet az élet- és vagyonbiztonságot veszélyeztető súlyos esemény - különösen elemi csapás vagy ipari szerencsétlenség - esetén, valamint ezek következményeinek az elhárítása érdekében lesz kihirdethető a hatályos rendelkezésektől eltérően, amelyek alapján csak három, tételesen meghatározott körülmény, az élet- és vagyonbiztonságot veszélyeztető elemi csapás vagy ipari szerencsétlenség, valamint ezek következményeinek az elhárítása teszi lehetővé a veszélyhelyzet kihirdetését. ${ }^{41}$ A tervezett reform egy szélesebben értelmezhető kihirdethetőségi feltétel - az élet- és vagyonbiztonságot veszélyeztető súlyos esemény megteremtésével rugalmasabbá és ezáltal az előre nem látható rendkívüli helyzetekben történő alkalmazáshoz jobban alkalmazkodóvá teszi a szabályozást. A katasztrófa típusú válsághelyzetek kezelésének alkotmányos szintü alapjait a következő ábra mutatja be.

\footnotetext{
38 Alaptörvény 53. cikk (3) bekezdés.

${ }^{39}$ Magyar Közlöny 2020/285. 10130.

${ }^{40}$ Magyar Közlöny 2020/285. 10130.

${ }^{41}$ Alaptörvény 53. cikk (1) bekezdés.
} 


\begin{tabular}{|c|c|c|c|c|}
\hline & \multicolumn{4}{|c|}{ A katasztrófa típusú válsághelyzetek kezelésének alkotmányos szintü alapjai } \\
\hline $\begin{array}{c}\text { Az } \\
\text { összehasonlitó } \\
\text { elemzés } \\
\text { szempontjai }\end{array}$ & \multicolumn{2}{|c|}{ Alkotmány } & Alaptörvény & $\begin{array}{c}\text { Alaptörvény } 9 . \\
\text { módosítása }\end{array}$ \\
\hline $\begin{array}{l}\text { különleges } \\
\text { jogrendi } \\
\text { esetkör } \\
\text { megnevezése }\end{array}$ & szükségállapot & veszélyhelyzet & veszélyhelyzet & veszélyhelyzet \\
\hline $\begin{array}{l}\text { kihirdetést } \\
\text { előidéző okok }\end{array}$ & $\begin{array}{l}\text { élet- és } \\
\text { vagyonbiztonság } \\
\text { ot tömeges } \\
\text { méretekben } \\
\text { veszélyeztető } \\
\text { elemi csapás } \\
\text { vagy ipari } \\
\text { szerencsétlenség }\end{array}$ & $\begin{array}{l}\text { élet- és } \\
\text { vagyonbiztonságot } \\
\text { veszélyeztető } \\
\text { elemi csapás, } \\
\text { illetőleg } \\
\text { következményeine } \\
\text { k az elhárítása, } \\
\text { valamint a közrend } \\
\text { és a közbiztonság } \\
\text { védelme }\end{array}$ & $\begin{array}{l}\text { élet- és } \\
\text { vagyonbiztonságot } \\
\text { veszélyeztető } \\
\text { elemi csapás vagy } \\
\text { ipari } \\
\text { szerencsétlenség, } \\
\text { valamint ezek } \\
\text { következményeine } \\
\text { k az elhárítása }\end{array}$ & $\begin{array}{l}\text { az élet- és } \\
\text { vagyonbiztonságot } \\
\text { veszélyeztető } \\
\text { súlyos esemény - } \\
\text { különösen elemi } \\
\text { csapás vagy ipari } \\
\text { szerencsétlenség, } \\
\text { valamint ezek } \\
\text { következményeine } \\
\text { k az elhárítása - }\end{array}$ \\
\hline $\begin{array}{l}\text { kivételes } \\
\text { hatalom } \\
\text { jogosultja }\end{array}$ & $\begin{array}{l}\text { köztársasági } \\
\text { elnök }\end{array}$ & Kormány & Kormány & Kormány \\
\hline $\begin{array}{l}\text { kivételes } \\
\text { hatalom } \\
\text { tartalma }\end{array}$ & $\begin{array}{l}\text { rendkívüli } \\
\text { intézkedések }\end{array}$ & $\begin{array}{l}\text { szükséges } \\
\text { intézkedések }\end{array}$ & $\begin{array}{l}\text { rendkívüli } \\
\text { intézkedések }\end{array}$ & $\begin{array}{l}\text { rendkívüli } \\
\text { intézkedések }\end{array}$ \\
\hline $\begin{array}{l}\text { kivételes } \\
\text { hatalom } \\
\text { ellensúlyozásár } \\
\text { a szolgáló } \\
\text { eszközök }\end{array}$ & $\begin{array}{l}\text { általános és } \\
\text { speciális } \\
\text { garanciák }\end{array}$ & $\begin{array}{l}\text { nincs } \\
\text { (kivéve: abszolút } \\
\text { jogok nem } \\
\text { korlátozhatók, } \\
\text { nem függeszthetők } \\
\text { fel) }\end{array}$ & $\begin{array}{l}\text { részletes általános } \\
\text { és speciális } \\
\text { garanciák }\end{array}$ & $\begin{array}{l}\text { még részletesebb } \\
\text { általános és } \\
\text { speciális garanciák }\end{array}$ \\
\hline
\end{tabular}

1. ábra.

A katasztrófa típusú válsághelyzetek kezelésének alkotmányos szintü alapjai (Forrás: Saját szerkesztés)

A jobb áttekinthetőség érdekében a szerzők az 1. ábrán bemutatják a katasztrófa típusú válsághelyzet-kezelés alkotmányos szabályozásának összehasonlítását. Látható a jogalkotói akarat megvalósulása azáltal is, hogy az Alaptörvény kilencedik módosításának hatályba lépését követően a továbbiakban az élet- és vagyonbiztonságot veszélyeztető súlyos esemény - különösen elemi csapás vagy ipari szerencsétlenség, valamint ezek következményeinek az elhárítása - érdekében lesz kihirdethető a veszélyhelyzet. 
A katasztrófák okozta károk a környezetet is pusztíthatják, nem csak a klasszikus értelemben vett emberi életet, egészséget és anyagi javakat. Meggyőződésünk, hogy a veszélyhelyzetek jogtörténeti áttekintésén belül is érdemes foglalkozni a környezetbiztonsággal, melynek szerepe az utóbbi években a világszerte - és ezen belül a hazánkban - végbement és jelenleg is zajló folyamatok, biztonságra negatívan ható tényezők hatására nagymértékben felértékelödött.

„A környezetbiztonság olyan állapot, amikor a társadalmi eredetü és a környezetre károsan ható események, illetve a müszaki eredetü katasztrófák bekövetkezésének valószinüségét megfelelö intézkedésekkel minimumra csökkentik, illetve katasztrófa esetén a keletkezett kárt úgy háritják el, hogy a hatás lehetöleg ne veszélyeztesse a természeti környezet minöségét és a lakosság egészségi állapotát." 42

Ennek az állapotnak a megteremtésében központi tényező a katasztrófavédelem rendszere. A katasztrófavédelem integrált szakmai területek összességének tekinthető, amelyben alapvető jelentősége van az élet- és vagyonbiztonság védelmének. Tevékenységi rendszerében az alkalmazott tudományok gyakorlati hasznosulása elengedhetetlen, azoknak társadalmilag kiemelten érzékeny és fontos eredményekkel kell szolgálniuk. ${ }^{43}$ Ennek a célnak a megvalósulásához is hozzájárulnak a legmagasabb szintü jogszabályban a katasztrófa típusú válsághelyzetekre vonatkozó rendelkezések, illetve a szabályozásokat, azok változásait vizsgáló tudományos munkák.

\section{Összegzés}

Dolgozatunkban rámutattunk, hogy a katasztrófák elleni védekezésben mindig meghatározó szerepe volt a különleges jogrend kihirdetésének. Ez alapvetően a rendszerváltozást követő vizsgált időszakban a veszélyhelyzet volt, illetve egy időszakban még a szükséghelyzet lehetett volna. A mindenkori Kormányok a katasztrófák elleni hatékony védekezés érdekében erős jogosítványokkal rendelkeztek, a jelentős katasztrófákat veszélyhelyzet kihirdetésével eredményesen lehetett kezelni, ám látható volt egy permanens korszerüsítési igény a részletszabályozásban fellelhető ellentmondások és a különleges jogrendi duplikáció elkerülésére.

Az új Nemzeti Biztonsági Stratégia rávilágított, a pandémia és a járvány következményeinek kezelése felhívta a figyelmet arra, hogy napjainkban és a közeljövőben hazánk változó biztonsági környezetében az elöre nem látható, ismeretlen, kiszámíthatatlan, dominóhatásszerü folyamatokat elindító rendkívüli helyzetek hatékony kezeléséhez megváltozott gondolkodásmódra és rugalmas szabályozásra van szükség.

Különös figyelmet kell fordítani a katasztrófakockázat átfogó csökkentésére. Magyarország katasztrófák elleni védekezésében meghatározó cél a képességalapú katasztrófavédelem megvalósítása, ebben nélkülözhetetlen a védelmi és biztonsági feladatok végrehajtása érdekében a különleges jogrendek, bennük a veszélyhelyzet kihirdethetőségének a korszerüsítése. A hazánkat fenyegető természeti és civilizációs katasztrófákat átfogó

\footnotetext{
${ }^{42}$ Német, Kátai Urbán, Vass 2020, 140.

${ }^{43}$ Ambrusz, Vass 2020, 49-50.
} 
megközelítéssel kell értelmeznünk, az ellenük való védekezés kormányzati irányítással, a védelmi igazgatás sikeres működésével lehet eredményes. A 2023. július 1-jén hatályba lépő alkotmányos reform ennek megfelelően világos, átlátható, ugyanakkor rugalmas, a 21. századi biztonsági környezethez jobban alkalmazkodó, megfelelő garanciarendszert tartalmazó, hatékonyabb szabályozási keretet alakított ki.

\section{A SZAKTERÜLETET SZABÁLYOZÓ LEGFONTOSABB JOGFORRÁSOK}

Magyarország Alaptörvénye

1995. évi LVII. törvény a vízgazdálkodásról

2011. évi CXIII. törvény a honvédelemről és a Magyar Honvédségről, valamint a különleges jogrendben bevezethető intézkedésekröl

2011. évi CXXVIII. törvény a katasztrófavédelemről és a hozzá kapcsolódó egyes törvények módosításáról

232/1996. (XII. 26.) Korm. rendelet a vizek kártételei elleni védekezés szabályairól

167/2010. (V. 11.) Korm. rendelet az országos nukleárisbaleset-elhárítási rendszerről

234/2011. (XI.10.) Korm. rendelet a katasztrófavédelemről és a hozzá kapcsolódó egyes törvények módosításáról szóló 2011. évi CXXVIII. törvény végrehajtásáról

290/2011. (XII. 22.) Korm. rendelet a honvédelemről és a Magyar Honvédségről, valamint a különleges jogrendben bevezethetö intézkedésekröl szóló 2011. évi CXIII. törvény egyes rendelkezéseinek végrehajtásáról

1/2019. (I. 31.) HM rendelet a honvédelmi ágazat katasztrófák elleni védekezésének irányításáról és feladatairól

27/2021. (I. 29.) Korm. rendelet a veszélyhelyzet kihirdetéséről és a veszélyhelyzeti intézkedések hatálybalépéséről

1150/2012. (V. 15.) Korm. határozat a Katasztrófavédelmi Koordinációs Tárcaközi Bizottság létrehozásáról, valamint szervezeti és működési rendjének meghatározásáról

62/2011. (XII. 29.) BM rendelet a katasztrófák elleni védekezés egyes szabályairól

A Katasztrófavédelmi Koordinációs Tárcaközi Bizottság 1/2016. (IV. 29.) határozata a Katasztrófavédelmi Koordinációs Tárcaközi Bizottság ügyrendjének és Katasztrófavédelmi Koordinációs Tárcaközi Bizottság Nemzeti Veszélyhelyzet-kezelési Központ ügyrendjének elfogadásáról 


\section{FELHASZNÁLT IRODALOM}

Ambrusz József, Vass Gyula 2020. Katasztrófavédelem a hadtudomány és a rendészettudomány határán. In $A$ hadtudománytól a rendészettudományig-társadalmi kihívások a nemzeti összetartozás évében, szerk. Gaál Gyula, Hautzinger Zoltán, 41-50. Pécs: Magyar Hadtudományi Társaság Határőr Szakosztály Pécsi Szakcsoport.

Az Alaptörvényhez és annak módosításaihoz tartozó indokolások. Indokolások Tára 2020/161. 1894-1900.

Jakab András, Till Szabolcs 2016. A különleges jogrend. In Bevezetés az alkotmányjogba: Az Alaptörvény és Magyarország alkotmányos intézményei, szerk. Trócsányi László, Schanda Balázs, 485-513. Budapest: HVG-ORAC Lap-és Könyvkiadó Kft.

László Viktória 2021. „A hatályos magyar szabályozás és a koronavírus-járvány első hulláma idején kihirdetett veszélyhelyzet során bevezetett kormányzati intézkedések vizsgálata”. Katonai Jogi és Hadijogi Szemle 9 (1): 43-76.

Magyarország Alaptörvényének kilencedik módosítása. 11. cikk. Magyar Közlöny 2020/285. 10128-10131.

Muhoray Árpád 2019. A veszélyhelyzetek kihirdetését igénylő helyzetek és azok korszerü megoldása a gyakorlatban. In A védelmi igazgatás müködésének gyakorlati tapasztalatai napjaink kihívásainak tükrében, szerk. Hornyacsek Júlia, 61-85. Budapest: Dialóg Campus Kiadó.

Német Alexandra. Kátai Urbán Lajos, Vass Gyula 2020. „Veszélyes tevékenységek biztonsága a fenntarthatóság jegyében”. Védelem Tudomány 5 (1): 137-152.

1949. évi XX. törvény a Magyar Népköztársaság Alkotmánya

1989. évi XXXI. törvény az Alkotmány módosításáról

Magyar Köztársaság Alkotmánya

1993. évi CX. törvény a honvédelemröl

1996. évi XXXVII. törvény a polgári védelemröl

Magyarország Alaptörvénye

2011. évi CXXVIII. törvény a katasztrófavédelemről és a hozzá kapcsolódó egyes törvények módosításáról

1163/2020. (IV. 21.) Korm. határozat Magyarország Nemzeti Biztonsági Stratégiájáról

40/2020. (III. 11.) Korm. rendelet veszélyhelyzet kihirdetéséről 